\title{
Ovarian Neuroendocrine Neoplasm
}

National Cancer Institute

\section{Source}

National Cancer Institute. Ovarian Neuroendocrine Neoplasm. NCI Thesaurus. Code C5237.

An epithelial neoplasm with neuroendocrine differentiation that arises from the ovary. It includes carcinoid tumor, small cell carcinoma pulmonary type, and large cell neuroendocrine carcinoma. 